\title{
International Exhaustion, Parallel Imports, and the Conflict between the Patent and Copyright Laws of the United States
}

\author{
Christopher J. Clugston \\ Law College, Keimyung University, Daegu, South Korea \\ Email: cjclugston@gw.kmu.ac.kr
}

Received May $5^{\text {th }}$, 2013; revised June $7^{\text {th }}$, 2013; accepted July $1^{\text {st }}, 2013$

\begin{abstract}
Copyright (C) 2013 Christopher J. Clugston. This is an open access article distributed under the Creative Commons Attribution License, which permits unrestricted use, distribution, and reproduction in any medium, provided the original work is properly cited.
\end{abstract}

\begin{abstract}
This article analyses the principle of international exhaustion - the doctrine that sales in a foreign country extinguish intellectual property rights. Many developed countries have pushed the international community not to recognize international exhaustion, and thus, to prevent parallel imports. However, the Supreme Court of the United States has recently held that there is exhaustion under US Copyright law for international sales. This is an unexpected holding and it creates a conflict between copyright law and patent law on the issue of international exhaustion. This article examines the effects and possible resolution of that conflict.
\end{abstract}

Keywords: International Exhaustion; First Sale; Patent Exhaustion; Copyright Exhaustion; Kirtsaeng; Ninestar; Jazz Photo

\section{Introduction}

International exhaustion is a controversial issue in international trade. It's even more so in our increasingly globalized world today. This controversy has become particularly heated in the United States, where the Supreme Court and the Court of Appeals for the Federal Circuit have given differing decisions on the issue in the areas of copyright and patent law, respectively. This article analyses the legal background, showing how the conflict developed, and also suggests that the proper resolution of the conflict is to recognize international exhaustion in the area of patent law to bring it in line with the other areas of intellectual property under United States law.

\section{The Law of Exhaustion}

Intellectual property rights (IPR) are often referred to as a bundle of exclusive rights granted to the IPR owner. In the case of patents, those exclusive rights include the right to make, use, offer for sale, sell and import the patented invention (Patent Act, 2012). And in the case of copyrights, those exclusive rights include the right to reproduce, create derivative works, distribute, import, and for certain categories, the right to publicly perform and publicly display the work (Copyright Act, 2004).

These exclusive rights, however, are not without limitation. Some of the rights can be extinguished by an authorized sale of a product. This is known as exhaustion or, alternatively, the first sale doctrine. The exhaustion doctrine was created to balance the monopoly power granted to IPR owners with the interests of the public by allowing the latter to use or dispose of lawfully acquired products as they choose, unencumbered (Calboli, 2013). Depending on where the first sale is made, exhaustion falls into one of two categories: national exhaustion or international exhaustion. IPR are territorial in nature; the rights are granted separately by each individual country and, mostly, only have effect in that country. As discussed below, this has led to a variety of different rules regarding exhaustion around the world.

\section{National Exhaustion}

Under national exhaustion, certain rights are extinguished after a domestic sale of a product covered by IPR. In order for the sale to exhaust exclusive rights, it must be an authorized sale by either the IPR owner or a licensee. Importantly, for a patented product, national exhaustion only extinguishes the right to use, offer for sale, and sell that particular product. Making and importing are not affected by a domestic sale (Calboli, 2013). Likewise, for a copyrighted product, national exhaustion will extinguish the distribution right for that product but will not affect the other rights.

The rationale behind the doctrine is that the IPR owner has received the full benefit of the IPR from the first sale. Thus, the purchaser should receive unencumbered ownership rights in that particular product. National exhaustion is a straight-forward and uncontroversial doctrine that is nearly universally recognized.

\section{International Exhaustion}

Conversely, international exhaustion is a far more contentious doctrine because of its effect on parallel imports. Parallel imports, or grey market goods as they are sometimes referred, are not fake or counterfeit goods. Instead, parallel imports are goods that are sold internationally by a patent owner (or a licensee) and then subsequently imported without permission. The products are genuine: they are made by or under the authority of the IPR owner. Parallel imports normally occur when 


\section{J. CLUGSTON}

an IPR owner attempts price discrimination among different countries or regions. In such situations, a third party that recognizes the arbitrage opportunity will purchase the product in a cheaper country for import and resale in a more expensive country. The legality of parallel imports varies from country to country.

In those countries that recognize the doctrine of international exhaustion, an authorized sale in a foreign country will extinguish certain of the IPR owner's rights. But whereas domestic exhaustion extinguished the exclusive rights of use and sale for patents, and of distribution for copyrights, the primary effect of international exhaustion is to extinguish the exclusive right to import for both ${ }^{1}$ (Calboli, 2013). That is, if IPR are owned in a country that recognizes the doctrine, the IPR owner cannot prevent the parallel importation of authorized products sold abroad because the owner's rights have been exhausted by the foreign sale. Thus, an IPR owners ability to control its products in international trade depends on if, and to what extent, the importing country recognizes international exhaustion. ${ }^{2}$

The issue of international exhaustion is such a contentious one in world trade that the parties to the Agreement on Trade Related Aspects of Intellectual Property Rights (TRIPS) could not negotiate any sort of agreement on the doctrine. In fact, the only mention of international exhaustion in TRIPS is a statement acknowledging the fact that the parties did not agree. Article 6 of TRIPS states the following: "For purposes of dispute settlement under this Agreement ... nothing in this Agreement shall be used to address the issue of the exhaustion of intellectual property rights” (TRIPS Agreement, art. 6, 1994). As such, each nation has the authority to determine the issue of international exhaustion. Because of this, the law of international exhaustion is a disordered mix of different rules depending on country or region. This is particularly so in the area of patent law.

\section{International Patent Exhaustion by Country}

Roughly, the disagreement over international patent exhaustion breaks down along developed and developing country lines. Developing countries tend to be net importers of intellectual property. Thus, these countries tend to support international exhaustion and parallel importation (Chiapetta, 2000). For a developing country, intellectual property is essentially a tax on its citizens that is being paid to the citizens of the exporting developed countries.

These proponents of recognizing international exhaustion, and thus allowing parallel imports, put forth a number of supporting arguments related to consumer welfare. First, such countries argue that parallel imports lower the costs for consumers. Allowing imports of lower priced goods can increase competition and force all prices lower. This can be particularly important in developing countries, where it can help to preserve access to medicine or other critical goods that may be covered by IPR. Many of the developing countries did not traditionally provide strong IPR protection for drugs but have been pressured to do so by developed countries through the WTO and TRIPs. Allowing parallel imports can be a way to help maintain access for the poor.

Proponents also make economic arguments for recognizing

\footnotetext{
${ }^{1}$ As well as any use, sale or distribution subsequent to the importation.

${ }^{2}$ There is no exclusive right to export, so the exporting country's law on international exhaustion is not relevant.
}

international exhaustion. By allowing parallel imports, markets will be more efficient. If all countries allowed parallel imports, then goods would flow freely. This would lead to a more efficient allocation of resources and better prices for all consumers in all countries. In addition, there is also a sense of economic fairness to international exhaustion. After a first sale, the IPR owner has received the reward for his efforts, allowing the owner to continue to prevent importation of the product into other markets is a sort of "double-dipping." Instead, international exhaustion respects traditional notions of property: once property is sold, all control over that particular item of property passes from seller to buyer.

Conversely, developed countries tend to be net exporters of intellectual property, and so, generally oppose international exhaustion and parallel importation (Chiapetta, 2000). As opponents of international exhaustion, these developed countries primarily assert two arguments. The first centers on the alleged positive aspects of price discrimination, and somewhat ironically, also claims to be best for the consumer. The ability to discriminate in price among different markets arguably allows a company to set prices based on the ability of consumers to pay in each market. Thus, in developing countries, an IPR owner can lower the price to be more in line with incomes, and in developed countries they can charge more. Without the protection from parallel imports offered in countries that don't recognize international exhaustion, the IPR owners would be forced to charge uniform prices worldwide. This would harm consumers in the developing world.

In addition, opponents argue that price discrimination is necessary to recoup research and development costs. IPR owners aren't able to charge monopoly prices in some countries, as mentioned above, because of a lack of consumer ability to pay. In addition, some countries artificially restrict prices by regulation. For example, although Canada is economically similarly situated to the United States, drug costs there are significantly lower because the Canadian government regulates prices. Because of the dual problem of countries where high prices are not possible as a practical matter, and countries where they are not possible as a legal matter, IPR owners, particularly drug companies, argue that they would not be able to recoup enough money to fund research and development without the ability to engage in price discrimination.

The second argument of the international exhaustion opponents relates to quality and safety concerns. Although parallel imports are authorized products, either made by the IPR owner or made under its authority, the importation is not authorized. As a result, the IPR owner cannot guarantee the quality or safety of the product. The unauthorized importer may not have used proper storage and handling techniques or may have even tampered with the goods in some way. In addition, where the imports are coming from a country with a different language, there are possible issues with instructions and warning labels.

Interestingly, although this division of opinion between developed and developing countries on the issue generally stands, on closer inspection, the reality is more complex. One of the main exceptions is a country like Norway or New Zealand. These are developed countries but they are also in favor of recognizing international exhaustion (Monten, 2005: pp. 417418). These countries have a high cost-of-living and a correspondingly high cost of patent covered goods. In such countries, the benefits of increased price competition from parallel imports for consumers can sometimes outweigh the benefits of 
greater protection for the patent owners in the country (Chiapetta, 2000).

Not all countries take an either or approach to the issue, taking an intermediate position instead. In the EU, for example, member states recognize international exhaustion on a regional basis. Thus, a product first sold in a member state will exhaust the patent owner's rights in all other member states. However, this first sale in the EU will not exhaust rights in non-EU countries, and a first sale in a non-EU country will not exhaust rights in any other country (Forsyth, 2007). Japan and Australia also take an intermediate position. Japan generally recognizes international exhaustion unless the purchaser in the foreign country has notice of the patent owner's rights (Chiapetta, 2000). And Australia does not recognize international exhaustion if there is a contractual restriction related to imports (US-Australia FTA, 2004).

\section{International Exhaustion in the United States}

Although the United States has long recognized international exhaustion in the area of trademark law, the country has traditionally been seen as one of the more staunch opponents of international exhaustion and parallel importation in the areas of copyright and patent law (Calboli, 2013). During the TRIPS negotiations, the United States took the lead among developed countries in arguing against recognition in these areas. Likewise, it has advanced this position in bilateral treaty agreements and has even gone so far as to put pressure on trading partners that have considered domestic laws that incorporate international exhaustion (Clapperton, 2006: p. 664) However, a recent Supreme Court case held that, in the area of copyright law, international exhaustion is recognized under United States law. Thus, a copyright owner cannot prevent the parallel importation of copyrighted products first sold in a foreign country. This case has called into question the continuing vitality of the non-exhaustion rule under United States patent law. Despite this, the Court of Appeals for the Federal Circuit (Federal Circuit) continues to espouse the position that there is no international exhaustion under United States Patent Law. As discussed below, this position is legally unsound.

\section{Federal Circuit Case Law: Jazz Photo Corp. v. Int'l Trade Comm ${ }^{3}$}

In Jazz Photo, the defendants were accused of importing refurbished, single-use cameras. These cameras were made by plaintiff Fuji, but some were first sold overseas, while others were first sold in the United States and sent overseas to be refurbished. After overseas refurbishing, the cameras were then imported into the United States for resell. The International Trade Commission (ITC) found all cameras to be infringing, regardless of the location of the original sale.

On appeal, the importers argued, inter alia, that there could be no infringement because the patent owner's rights had been exhausted. With respect to the cameras first sold overseas, the Federal Circuit disagreed, stating that "United States patent rights are not exhausted by products of foreign provenance." ${ }^{4}$ In holding that the first sale doctrine only applies to sales that occur in the United States, the Federal Circuit improperly relied on the Supreme Court decision in Boesch v. Graff for support.

Despite the Federal Circuit's reliance, the facts of Boesch do

${ }^{3} 264$ F.3d 1094 (Fed. Cir. 2001).

${ }^{4}$ Id. at 1105 .

${ }^{5} 133$ U.S. 697 (1890). not actually involve the issue of international patent exhaustion. In Boesch, the owners of United States and German patents covering oil lamp burners brought suit alleging that burners purchased in and imported from Germany by defendants infringed the US patents. Defendants argued that there could be no infringement because they purchased their burners lawfully from a third-party, one Mr. Hecht, who had a right to sell them in Germany. Although Hecht did have the right to make and sell the patented burners in Germany, his rights arose under a provision of then-German law that gave a type of prior-use rights to those "who, at the time of the patentee's application, have already commenced to make use of the invention in the country..." ${ }^{6}$ Hecht was not a licensee of or otherwise connected to the patent owners. Because he had no connection to the patent owners, a purchase from him cannot be considered a first sale that exhausts the owners' rights. The rationale behind the exhaustion doctrine, whether domestic or international, is that the patent owner has received the benefit of the patent from the first sale. A sale by an unrelated third party, such as Hecht, thus does not involve the exhaustion issue at all.

Since the Jazz Photo decision, the Federal Circuit had been somewhat inconsistent in its rulings on international exhaustion. In one line of cases, the Court relied on Jazz Photo to deny recognition of international exhaustion ${ }^{7}$ while in another, it twice applied international exhaustion to imported goods manufactured and first sold abroad. ${ }^{8}$ Any doubt about the Federal Circuits position on the issue, however, was resolved against international exhaustion in its Ninestar decision. ${ }^{9}$ The facts of Ninestar are similar to Jazz Photo, in that both involved the import of refurbished products. ${ }^{10}$ In Ninestar, the court reiterated its support for the wrongly decided Jazz Photo line of cases, holding that a foreign first sale cannot exhaust domestic rights. However, the Supreme Court has further called this line of cases into questions with its recent international copyright exhaustion decision.

\section{Supreme Court Case Law: Kirtsaeng v. John Wiley \& Sons, Inc. 11}

The Kirtsaeng decision finally resolved a long going battle over the legality of parallel imports under United States Copy${ }^{6}$ Id. at 701 .

${ }^{7}$ See Fuji Photo Film Co. v. Int'l Trade Comm,. 386 F.3d 1095 (Fed.Cir.2004); Fuji Photo Film Co. v. Jazz Photo Corp., 394 F.3d 1368 (Fed.Cir.2005); Fuji Photo Film Co., Ltd. v. International Trade Comm., 474 F.3d 1281 (Fed. Cir. 2007); Fujifilm Corp. v. Benun, 605 F.3d 1366 (Fed. Cir. 2010).

${ }^{8}$ See Powertech Tech. Inc. v. Tessera, Inc. 646 F.3d 1357 (Fed. Cir. 2011).; Tessera, Inc. v. Int'l Trade Comm'n 646 F.3d 1357 (Fed. Cir. 2011).

${ }^{9}$ Ninestar Tech. Co. Ltd. v. Int'l Trade Comm., 667 F.3d 1373 (Fed. Cir. 2012).

${ }^{10}$ In Ninestar, the defendant refilled and imported used ink cartridges that were first sold abroad by plaintiff Epson. Ninestar appealed a finding of infringement by the ITC, arguing to the Federal Circuit that Epson's patent rights had been exhausted by the foreign sale. Ninestar suggested the Jazz Photo line of cases had been overruled by the intervening Supreme Court decision in Quanta Computer, Inc. v. LG Elecs., Inc., 553 U.S. 617 (2008). The Quanta case specifically involved the issue of domestic, not international, exhaustion. However, the Court did suggest support for recognizing international exhaustion in a note to the main decision. Further, when the case was returned to the lower court for a decision on the international exhaustion issue, that court held that, under the Quanta decision, international exhaustion did extinguish patent rights. The Federal Circuit denied relief, stating that Quanta was legally and factually distinguishable. The Supreme Court dealt only with the issue of domestic exhaustion so Quanta was, according to the Federal Circuit, irrelevant to the issue of international exhaustion.

${ }^{11} 2013$ US LEXIS 2371 (2013). 
right law. Prior to the decision, a split of authority had developed on the issue-the Second Circuit held that international exhaustion does not apply to copies manufactured outside of the United States, ${ }^{12}$ the Ninth Circuit held that international exhaustion does apply to copies manufactured outside of the United States, but only if first sold in the United States, ${ }^{13}$ and the Third Circuit stated that a limitation of the first sale doctrine to only those copies made within the United States "does not fit comfortably within the scheme of the Copyright Act."14

In Kirtsaeng, the accused infringer was a Thai citizen attending graduate school in the United States. Kirtsaeng noticed that there was a significant discrepancy between the prices of textbooks in Thailand and in the United States and he took advantage of this by asking his friends and family in Thailand to purchase copies of these cheaper foreign versions and mail them to him. Kirtsaeng would then sell the textbooks online, reimburse his friends and family for the purchase and shipping costs, and keep the profit for himself.

Among the books imported and sold by Kirtsaeng were many that were made and first sold abroad by John Wiley \& Sons (Asia) Pte Ltd. These foreign textbooks generally contained language stating that the book could only be sold in a particular country and could not be imported into the United States. ${ }^{15}$ When Wiley brought suit for violation of its rights of importation and distribution, Kirtsaeng argued that these rights had been exhausted by the first sale in Thailand. The trial and appellate courts both found infringement, with the appellate court stating that the first sale doctrine only applies to copies "made in territories in which the Copyright Act is law."16

The Supreme Court reversed the lower court decisions, and made it clear that international exhaustion is recognized, stating as follows:

In our view, $\$ 109(a)$ 's language, its context, and the common-law history of the "first sale" doctrine, taken together, favor a non-geographical interpretation. We also doubt that Congress would have intended to create the practical copyright-related harms with which a geographical interpretation would threaten ordinary scholarly, artistic, commercial, and consumer activities. ${ }^{17}$

In doing so, the Court resolved one legal issue but created another. The split of authority under United States Copyright Law is now settled. However, this has caused a conflict between copyright law and patent law on the treatment of international exhaustion.

\section{Conclusion}

Because of this conflict, I believe that the Federal Circuit's continued opposition to international exhaustion in patent law is untenable. The Jazz Photo line of cases improperly relies on Boesch as precedent and is, thus, legally unsound. As discussed, the Boesch case does not involve a first sale by or under the authority of the patent owner. Such a sale can have no effect

\footnotetext{
${ }^{12}$ Kirtsaeng v. John Wiley \& Sons, Inc., 654 F.3d 210, 213 (CA2 2011).

${ }^{13}$ Omega S. A. v. Costco Wholesale Corp., 541 F.3d 982, 986 (CA9 2008).

${ }^{14}$ Sebastian Int'l, Inc. v. Consumer Contacts (PTY) Ltd., 847 F.2d 1093, 1098 (CA3 1988).

${ }^{15}$ Kirtsaeng, at 13 (2013) (the Asian edition of these books said, in relevant part, that the "book is authorized for sale in Europe, Asia, Africa, and the Middle East only and may be not exported ... Exportation from or importation of this book to another region without the Publisher's authorization is illegal and is a violation of the Publisher's rights.”).

${ }^{16}$ Id. at 17 .

${ }^{17}$ Id. at 19 .
}

whatsoever on the importation rights of the patentee. Patent exhaustion only applies when the patent owner obtained some benefit, either directly or indirectly, from the first sale. A sale by an unrelated third-party with only prior user rights confers no benefit on the patent owner and extinguishes no right. Without sound precedent, then, the various rationale for recognizing international copyright exhaustion will have implications for whether to recognize international patent exhaustion.

Patent and copyright laws have much in common. Thus, they frequently borrow legal concepts from one another and, more importantly, they both have the same policy objectives. Unlike other areas of IPR, the protection of both patent and copyright are grounded in the Intellectual Property Clause of the Constitution, which grants authority "to promote the Progress of Science and the Useful Arts by securing for limited Times to Authors and Inventors the exclusive Right to their Writings and Discoveries.” (US Const, art. I, § 8, cl. 8). This clause encapsulates the bargain theory of IPR. That is, the balance between the rights of the inventor to exploit his invention or work, and the rights of the public to have access to and use of the knowledge embodied in the invention or work. Under the bargain theory, the purpose of intellectual property is to incentivize the creation of more and better things, but to do so for the ultimate benefit of the public. Because of these similarities between the two areas of the law, it can be instructive to analyze international patent law exhaustion using the reasoning of the Court in Kirtsaeng.

\section{Implications of Kirtsaeng on International Patent Exhaustion}

Although a large part of the Court's decision dealt with the proper interpretation of the exhaustion clause of the Copyright Act, it also relied on three rationales that were important to the patent exhaustion issue. First, the Court focused on the common law history of the first sale doctrine. The Court pointed out that the general doctrine of first sale had "an impeccable historic pedigree." 18 Citing a 17th century treatise by Lord Coke for support, the Court explained how any law that would allow a seller of a chattel to control its resale or other disposition would be "against Trade and Traffi[c], and bargaining and contracting."19 Consumers benefit when buyers are free to dispose of their lawfully acquired goods without restriction. This benefit is achieved through increased competition among buyers when they resell these goods and requires that there be no ongoing encumbrances. Further, another rationale underlying the common law doctrine was that it would decrease the burden on the judicial system. Downstream restrictions on goods are difficult to trace and to enforce. As a result, such restrictions are often selectively enforced. Importantly, the Court noted, the historical common law first sale doctrine made no geographic distinctions so there was a presumption that the modern statutory doctrine also made no such distinction.

This historical argument from the common law is even stronger for patent law than it is for copyright law. The Copyright Act contains a clause specifically dealing with the issue of exhaustion by first sale. Thus, in analyzing the international exhaustion under copyright law, opponents of recognition at least have the argument that the relevant statutory clause repre-

\footnotetext{
${ }^{18} \mathrm{Id}$.

${ }^{19}$ Id. at19, citing Coke, E. Institutes of the Laws of England §360, p. 223 (1628).
} 


\section{J. CLUGSTON}

sented a departure from historical precedent. However, the Patent Act contains no such clause. Instead, the issue of international patent exhaustion is decided purely by court decision. From the time of Lord Coke's treatise, the common law has strongly favored recognition of the general doctrine of exhaustion. Thus, without a strong and unambiguous precedent on which to rely, the Federal Circuit's arbitrary decision to only recognize exhaustion domestically is not on sound legal footing.

Second, the court looked at possible harms that would result from not recognizing international exhaustion. Many common consumer goods, such as "automobiles, microwaves, calculators, mobile phones, tablets, and personal computers" contain copyrighted components, often in the form of software. ${ }^{20}$ If a first foreign sale did not exhaust these rights, the purchaser would not be able to resell his product in the United States. Instead, permission would be required from the owners of any and all copyrights contained in the product. This would place an unworkable burden on trade in such goods.

The Court's concern over these negative effects on international trade applies equally well in the area of patent law. The concern of the Court specifically was over software included in these consumer products that might be protected by copyright. However, this same concern is raised by patent protection because software can be patented in the United States. As such, the same software could interfere with the free trade of these same goods in the same way if international exhaustion is not recognized in the area of patent law. In other words, the respective decisions of the Supreme Court in Kirtsaeng and of the Federal Circuit in the Jazz Photo line of cases have created a scenario where the exact harms the Court is trying to prevent in its decision are being enabled by the Federal Circuit in its contrary decision. Such an absurd result runs counter to legal reasoning.

Finally, in responding to the argument that recognizing international exhaustion would make it difficult to price discriminate, the Court analyzed the Intellectual Property Clause of the Constitution. Wiley argued that it would be difficult, if not impossible, for a copyright owner to charge different prices in different markets without the ability to prevent parallel imports from those markets where the product was sold at a lower price. The Court responded by pointing out that the Constitution did not suggest that a right to divide markets and price discriminate exists. Because price discrimination is not one of the bundle of rights protected by a copyright, it is of no legal importance whether recognizing internal exhaustion will frustrate a copyright owners ability to do so.

The Court's discussion of the Intellectual Property Clause of the Constitution is also on point when considering international patent exhaustion. There is no right to or guarantee of the ability to discriminate on price inherent in the patent laws. Thus, any argument against international exhaustion or parallel imports must rely on other grounds. However, such other grounds, as discussed above, are also questionable.

Because of the contrary holding in Kirtsaeng, the issue of international exhaustion in patent law needs to be addressed. At its first opportunity, the Federal Circuit should order en banc review of this issue. The current position of the court is not supported by precedent and is at odds with the Supreme Court in the related area of international copyright exhaustion. In addition, the rationale justifying the Court's decision on copyright exhaustion apply equally, or even moreso, to the issue of patent exhaustion. As such, the Federal Circuit's position is wrong on both the law and the policy and needs to be addressed.

\section{Acknowledgements}

The present research was funded by a BISA Research Grant of Keimyung University.

\section{REFERENCES}

(1994). Agreement on Trade-Related Aspects of Intellectual Property Rights, April 15, 1994, 33 I.L.M. 81 [TRIPS Agreement].

Boesch v. Graff, (1890). 133 US 697.

Calboli, I. (2013). Corporate strategies, first sale rules, and copyright misuse: Waiting for answers from Kirtsaeng v. Wiley and Omega v. Costco (II). Northwestern Journal of Technology \& Intellectual Property, Forthcoming, 11.

Chiapetta, V. (2000). The desirability of agreeing to disagree: The WTO, TRIPS, international IPR exhaustion and a few other things. Michigan Journal of International Law, 333.

Clapperton, D., \& Corones, S. (2006). Locking in customers, locking out competitors: Anti-circumvention laws in Australia and their potential effect on competition in high technology markets. 30 Melbourne U. L. Rev. 657.

Forsyth, N., \& Rothnie, W. (2007). Parallel imports, in the interface between intellectual property rights and competition policy. Cambridge: Cambridge University Press.

Fujifilm Corp. v. Benun, 605 F.3d 1366 (Fed. Cir. 2010).

Fuji Photo Film Co. v. Int'l Trade Comm., 386 F.3d 1095 (Fed.Cir. 2004).

Fuji Photo Film Co. v. Int'l Trade Comm., 474 F.3d 1281 (Fed. Cir. 2007).

Fuji Photo Film Co. v. Jazz Photo Corp., 394 F.3d 1368 (Fed.Cir.2005)

Intellectual Property Clause, U.S. Const., art. I, 99 8, cl. 8.

Jazz Photo Corp. v. Int'l Trade Comm., 264 F.3d 1094 (Fed. Cir. 2001).

Kirtsaeng v. John Wiley \& Sons, Inc., 2013 U.S. LEXIS 2371 (2013).

Kirtsaeng v. John Wiley \& Sons, Inc., 654 F.3d 210 (CA2 2011).

Monten, L. (2005). The inconsistency between section 301 and TRIPS: Counterproductive with respect to the future of international protection of intellectual property rights. 9 Marq. Intellectual Property L. Rev. 387.

Ninestar Tech. Co. Ltd. v. Int'l Trade Comm., 667 F.3d 1373 (Fed. Cir. 2012).

Omega S. A. v. Costco Wholesale Corp., 541 F.3d 982 (CA9 2008) aff' $d$ by an equally divided court, 562 US (2010).

Powertech Tech. Inc. v. Tessera, Inc., 660 F.3d 1301, 1307 (Fed. Cir. 2011).

Quanta Computer, Inc. v. LG Elecs., Inc., 553 U.S. 617 (2008).

Sebastian Int'l, Inc. v. Consumer Contacts (PTY) Ltd., 847 F.2d 1093 (CA3 1988).

Tessera, Inc. v. Int'l Trade Comm'n, 646 F.3d 1357 (Fed. Cir. 2011).

US-Australia FTA (2004). United States-Australia Free Trade Agreement, May 18, 2004, T.I.A.S. No. 6422.

http://www.ustr.gov/trade-agreements/free-trade-agreements/australi an-fta/final-text

United States Copyright Act, 17 U.S.C. §§ 106, 602 (2004)

United States Patent Act, 35 U.S.C. § 271 (2012)

\footnotetext{
${ }^{20}$ Id. at 39 .
} 